\title{
Performance Analysis on Spa Service at Badung and Gianyar Regencies
}

\section{Dewa Ayu Laksmiadi Janapriati, I Made Sukarsa and Nyoman Adiputra}

\author{
School of Postgraduate Study \\ Doctorate Degree in Tourism Udayana University \\ Coressponding author: laksmi.palguna@yahoo.com
}

\section{ARTICLE INFO}

Received

26 February 2014

Accepted

07 August 2014

Available online

10 September 2014

\section{ABSTRACT}

Over the last ten years, spa as one of the products of wellness tourism is growing very fast in Bali, necessitating the development strategy in accordance with the conditions of Bali. The rapid development momentum for the business of spa is opened in Bali, although in the external side of the business will compete with the international trade environment to take advantage and create sustainable economic growth prospects. This will be an opportunity for Bali as a destination spa in the future. In an effort to maintain and continue to develop quality as the best spa destinations in the world, we need the right strategy to make the creation and supporting product innovation spa in Bali. This study aims to create an integrated assessment of the extent of the influence of the utilization of natural resources, human resources and local knowledge of the existence and essence of spa in Bali and methods for utilizing natural resources, human resources and local knowledge of Bali on development of spa in Bali. Research design and methods of approach to the problem that are done in this study using descriptive design, where the planning and execution of research conducted in the form of field data are collected in the form of surveys, questionnaires and statistical data processing. The target population in this study is divided into three, namely: the company or a place that offers spa services, spa services supporting manufacturers and both foreign and domestic tourists who use the services of spa services in Badung and Gianyar, by assuming the two districts can represent the tourist population to Bali. Based on several case studies found that the performance of spa services in terms of utilization of natural resources, human resources, and local wisdom of Bali, particularly in terms of (1) the atmosphere (ambience), (2) equipment and design, (3) the qualifications and skills of the therapist, (4 ) treatment menu, and (5) the quality of services as a whole has shown good performance. Consumer expectations of the spa service indicators in terms of utilization of natural resources, human resources, and local wisdom of Bali, particularly in terms of (1) the atmosphere (ambience), (2) equipment and design, (3) the qualifications and skills of the therapist, (4). The treatment menu, and (5) the quality of services (service) as a whole have demonstrated the value of important categories.

Keywords: Spa, local natural resources, development, Bali.

\section{Introduction}

\section{Background}

Many researches have been done about the quality of services and satisfaction of marketing, but only a few attentions has been

http://ojs.unud.ac.id/index.php/eot carried out to analyze the perception of service quality to customer satisfaction in the spa industry. It is very important for spa services industry in understanding and measuring the impact of service quality to customer satisfaction. The feedback obtained from these 
practices can be used to make the strategy improvements in production services and that will have an impact on the business, and ultimately increase profitability. Therefore, research is needed to determine the relationship between perception of service quality and improvement strategies that must be done in the spa industry in Bali. Bali as an international tourism destination has integrated health and wellness spa in particular as a unit of hotel services in the tour package. This refers to the reality in which most of the hotels in Bali have to equip their products with the spa services, especially health and wellness spa should be developed and enhanced in accordance with the expectations of the tourists or consumers. Efforts to develop and improve the quality of spa services that already exist in Bali, a destination product differentiation and uniqueness of existing destinations, so expect the Bali tourism destinations can be expanded both in service and management.

Although the spa is one of the market segments that are growing most rapidly in the hospitality and tourism industry, some of the studies mentioned above are still focused on the aspects of operational benefits and demographic profile of the spa. No attention is devoted to the perception of the benefits and influence the motivation of the spa customer. Therefore, research is needed that focuses more on the theory of planned behavior as a theoretical framework to examine the behavior and motivation of the customer in assessing the performance of the spa.

Local wisdom Bali as Bali and cream massage techniques examined in this study, to determine its contribution in the development and determine the existence and essence as well as the performance of services in Bali spa. Bali as the best spa destinations in the world should be developed into Spa Capital of Asia. Spa business has been in a state of competitive international trade environment, so as to make this spa business as a real business opportunity, profitable, competitive and sustainable, it is necessary to integrated research, which includes research on the performance of services in terms of utilization spa natural resources, human resources, and local knowledge of Bali and supporting product development services spa services.
This study also analyzes the performance in terms of several indicators spa services to develop and improve the quality spa services in accordance with the expectations of the tourists, such as: the atmosphere (ambience), equipment and design, qualification and skills of therapists, treatment menu and quality of service (service). In order to maintain high professional standards in the spa industry and ensure that the performance of the spa in Bali in accordance with international standards, some new indicators, in addition to the seven indicators mentioned above, is added which includes: (1) Facilities and Equipment, which is a spa should have governance planned layout with due consideration of privacy, security, cleanliness, and the other - the other, especially should have a hydro-therapy facilities. (2) Service, the spas should provide a variety of services, which include: massages, aroma therapy, hydro-therapy, beauty therapy, body wrap and scrub, spa-related product sales-products. (3) Health services which may include diet and nutritional advice, health screening, as well as slimming services.

At the end of the study, it will be assessed a few things, such as: management commitment, quality, communication, product development, business practices in general, promotion, business transactions, recruitment, training and staff development, professionalism, tangibles, the general environment, mastery of equipment, operational requirements, and operational procedures. The end result of this study is the integrated study of the extent of the effect of the utilization of natural resources, human resources and local knowledge on the performance of the spa services in Bali and methods for utilizing natural resources, human resources and local knowledge in the development of spa in Bali Bali.

\section{Research Objectives}

1. Analyzing spa service performance in terms of utilization of natural resources, human resources, and local wisdom Bali.

2. Analyzing the effect of the utilization of natural resources, human resources and local knowledge of the existence and the essence of spa in Bali. 


\section{Literature Review}

Research on tourism are now widely performed by researchers in the country and abroad. Some of these studies have been able to scientifically contribute ideas to support the field of tourism and science. However, if examined in depth there are still certain areas of space and still worthy to be studied. One is research on the number of spa increasing demand internationally. Before describing the concept of research, first presented some research results related to the spa in Bali and abroad so that the gap between previous studies and research more clearly visible.

Several cases of tourism destinations in Bulgaria, Canada, and Portugal indicate that the business of health and wellness has an important role in tourism development. The role of business in the health and wellness destination has become an integral part of the main services in hospitality services. Most services have rooms equipped with services, especially health and wellness spa as a package tour (Supapol, Barrows and Barrows, 2007; Quintela, Correia and Antunes, 2011). Health concept contains elements of lifestyle, physical, mental, and spiritual well-being, and one's relationship to oneself, others, and the environment, welfare, happiness, quality of life, holistic practices and spiritual beliefs, therapies beauty, massage, spa, sauna, relaxation, energy balancing, art, music and a variety of treatments. Fitness tourism concept containing products and services and has a wider meaning than the concept of health (Schüler, Sheldon and Fröhlich, 2010; Smith and Puczkó, 2010).

In some countries, wellness or fitness often located in rural or always associated with the natural environment, so the fitness tour is an important part of the natural environment, be it natural resources and natural scenery. The dominance of services in the spa industry, should pay attention to the problem of perception, quality of service and customer satisfaction. Customer perception in spa services providers determine the success of spa services. From the standpoint of management, managers must systematically examine the type of service from their current customers and to innovate in perspective by redesigning their products and environmental

http://ojs.unud.ac.id/index.php/eot services on which their services are presented as their target customers (Oliver, 1981; MacKay and Fesenmaier, 2000). The availability of qualified spa services, is critical to customer satisfaction. In the spa services industry, offers a high quality, personal, tailormade, and the exclusive massage services and fitness, is the key to achieve customer satisfaction spa (Zeithaml, Bitner and Gremler, 1996; MacKay and Fesenmaier, 2000).

Quality of care is focused evaluation which reflects the perception of customers, such as the quality of the interaction, the quality of the physical environment and the quality of the results. This service indicator in turn evaluated based on certain dimensions of service quality. Quality of service as a measure of how well the level of service delivered according to the expectations of the customers. Quality of service is regarded as the overall analysis of the attitude of service excellence (Lewis and Booms, 1983). Quality of service is a comparison between the performance of perceptions with expectations while; or the comparison of performance against the standard or ideal; or a comparison between the technical quality (what is delivered) and the quality functional (how to run) as well as a comparison between the quality of the process (which is assessed during service) and quality of the output (rated after the service). Quality in business services in terms of the size of the extent to which the services are carried out in accordance with the expectations of the customers. The quality of perception is influenced not only by the results of the service, but also by the service process (Grönroos, 1984; Parasuraman, Zeithaml and Berry, 1985; Cronin Jr and Taylor, 1992).

Customer satisfaction is the fulfillment of the needs and expectations of customers, where customer expectations are the most direct determinant of customer satisfaction (Oliver, 1981; Zeithaml, Bitner and Gremler, 1996; Kim, 2002). Customer satisfaction varies from one person to another and from one product to another, depending on the psychological and physical variables of customers, and correlated with a particular behavior of the customer. Judging from the psychological variables, the personal beliefs, attitudes and evaluations affect customer satisfaction. Customer satisfaction is a reliable 
indicator of where the customers interested in coming back. Dissatisfied customers tend to be less committed and certainly will not return to the service providers. Loyal customers or those who enjoy a positive experience of the services they receive can be used as a good basis to declare the level of customer satisfaction. This is because they tend to have better social interaction with the service provider and can create customer satisfaction, which in turn causes the customer's intention to come back. Customer satisfaction has a stronger effect and more consistent on the intention to try a service compared to the quality of the service itself.

Business spa in the hotel and resort is a market segment that is growing most rapidly in the hospitality and tourism industry, with average growth - an annual average of $20 \%$ in the last eight years. Traveler profile distinguishes spa types, namely traditional spas, hotel spas and day spas. also built spa recreation, seaside resorts and thalassotherapy, and five other types of health, namely a holistic fitness center, yoga center, meditation fitness and wellness center (Supapol, Barrows and Barrows, 2007). Rapid growth and strong demand on spa tourism industry because consumers who have high incomes, seeks to indulge, seek better health and fitness. Spa improving lifestyle, beauty and better health, revitalize the mind, body and soul.

Malaysia, as a multi-cultural country, has the capability and a large number of traditional spa treatments handed down from generation to generation. Total spa in Malaysia has grown more than $200 \%$ since 2002 . The world economic crisis has changed the demographic and cultural attitudes of consumers towards the consumption culture component of health and wellness products are increasing. Over the last decade, the spa and wellness has grown rapidly in Bali and generate high income. Spa services need to be measured performance to realize the satisfaction of tourists, tourism destinations must have the appropriate development strategy Balinese culture (Widjaya, 2011). Services spa services increasingly complex because it is not limited to entertainment and recreation, the development of a healthy lifestyle also encourages the development of this spa services business.

http://ojs.unud.ac.id/index.php/eot
Refers to some of these studies, so in this study will be reviewed by foreign tourists motivation to perform spa in Bali and the performance of services as well as its development strategy in accordance spa Balinese culture. Local wisdom Bali as Bali and cream massage techniques examined in this study, to determine its contribution in the development and determine the existence and the essence of spa in Bali. Bali as the best spa destinations in the world should be developed into Spa Capital of Asia.

In general, consumer's wellness according to Barnes, Goc Karp and Stoll (2008) is wellness-focused, moderate-to-active spa goers. This group includes people who have a very high interest in living, healthy lifestyle, and always improving or maintaining the health and fitness level. These consumers tend to be educated and relatively affluent, and their profiles parallel in many ways. They are open to new and different approaches to health, sports, and beauty; they have the time and disposable income to spend on these things; they did not see the spa and wellness services as a luxury, but has become a necessity and has special attention to the problem of aesthetic appearance and the effects of aging. Both are Sickness reactors, not active spa-goers. This group is looking for people with the disease and new alternative approach to treat disease or relieve the symptoms of the disease. This consumer frustrates with the inability of the current medical system to cure them. As a result, they are exploring alternative approaches. This segment is a segment of a much larger potential, and look for an alternative approach. This phenomenon is relatively similar to the kind of treatment both in Bali. In the development of wellness tourism, tourist motivation to do a spa is to enjoy the beautiful nature for the purpose of leisure and look and feel the sensation of ingredients and spices for health tourists.

\section{Research Framework}

Bali's image as a popular spa destination is supported by a number of factors, which are as follows. (1) Bali has been able to offer spa services by utilizing natural resources, and local ingredients. (2) Spa has become part of the culture of Bali. (3) Characteristics of local 
Balinese therapists are considered quite well. (3) Spa Bali is a holistic approach in dealing with tourists. (4) Availability of native spices that give support to the spa industry. (5) Bali has methods Taru Pramana Usada and literature can be studied further to the development of local wisdom. The fifth of these advantages become an attraction for tourist to enjoy spa services during a vacation in Bali. Nonetheless, there are some things that should be observed and the rationale in this study. The basic idea is the following. (1) The low number of certified therapists' profession. (2) The majority of spa personnel not formally educated and qualified spa. (3) Lack of service standards spa. (3) Permission and spa qualifications is less clear so as to establish spa services businesses still use permit from the local authorities. (4) There are still a lot of energy spa therapists who work in Bali less quality because quality instead chose to work abroad. (5) Spa in Bali is not supported by the supporting industries spa, such as furniture, materials - materials that are standardized and patented. (6) Spa in Bali has not been supported by high-tech equipment. (7) The number of available therapists are still not able to meet the needs of the market demand. (8) The majority of the spa managers have no formal training in governance spa.

Effort to maintain and develop Bali as the best spa destinations in the world, required creativity and innovation to the spa products and its services. Creation and innovation requires deep research related to quality spa products that have been developed at this time. The study is expected to see a number of indicators of the quality of the spa business traveler expectations in the decision to choose a service spa. These indicators are: (1) the atmosphere (ambience), (2) equipment and design, (3) the qualifications and skills of the therapist, (4) treatment menu, and (5) the quality of services. This line of thought can be described as in Figure 3.1 below. In principle, the spa business is a business of care (treatment), which combines the atmosphere, media, natural materials, and therapy skills. Development of spa tourism is charged locally to strengthen the position of Bali as a world tourism destination. The development of creativity and innovation services (service) and spa products that utilize local resources requires research into the elements - elements such as element spa business services and products that are expected by tourists in choosing a spa. The conduct an analysis of the elements that become tourist expectations can determine indicator - an indicator of what do I need to be maintained, developed, and improved quality. This study also aimed to determine the performance of products and services based on the perception of tourists' spa services.

\section{Concepts}

Efforts to develop spa tourism competitiveness can strengthen the image of Bali as a destination spa in Bali. Effort - effort requires a deep study, integrated research and thorough analysis of the elements - elements forming spa products and services that have been developed in Bali today. In the conditions of competition spa destination today, factors - factors that affect customer satisfaction should be known, so that the spa industry in Bali can be laid out better.

This research was conducted in Badung, in Nusa Dua, Jimbaran and Kuta, and in Gianyar is located in the Ubud area. This study was conducted using a survey of providers that offer spa services. Survey of spa services providers are expected to know the various natural resources, human resources, and local technology that has been utilized in development efforts spa in Bali. Another expectation can be described about how the service providers utilizing the spa services of natural resources, human resources and local Balinese massage techniques, to support the existence and essence of the spa and spa services performance in Bali. Results of this study were analyzed using analysis of the level of interest is expected to analyze the performance of the service spa in Badung and Gianyar in terms of utilization of natural resources, human resources, and local wisdom of Bali, as well as its relationship with spa services that have been developed in Bali.

\section{Product performance and customer satisfaction of spa}

Once the magnitude of the role of consumer satisfaction on consumer loyalty so important to know the factors - factors that influence it. In the context of this study, the 
hope - consumer expectations reflected in the motivation of consumers to enjoy spa services so the motivation is important to investigate. In the business context, efforts to achieve customer satisfaction is a continued effort to achieve customer loyalty. To achieve customer satisfaction special on spa services business, various factors may include natural resources, service methods applied, and human resources. Natural resource is anything that comes from nature that can be used to meet the needs of human life. In this study, the natural resource in question is a resource in the form of herbs and plants that are more commonly called spice - spice that has been used as raw materials in products and services in Bali spa. In this study, the definition of human resources workforce is competent and professional in the field of so-called spa therapists. The therapist plays an important role and be a key to the success of a spa service. The success of Bali to be "The Best Destination Spa in the World" is not supported by scientific basis of health in the country and internationally patented.

Local wisdom referred to in this study are a variety of unique spa services that can only be found in Bali, such as traditional Balinese massage techniques, services based hospitality of the Balinese, and the uniqueness of others that affect the performance of services in Bali spa. While the spa service indicators in this study was developed by considering the amount of local content elements have been applied in the industrial and business service spa. Indicator - an indicator of the spa services as follows: method Bali in spa massage techniques, the latest methods in the technique of massage spa, Balinese, physical care, surgery time, the realization of the promise, sympathy and attitude, characteristic of the Balinese therapists, the accuracy of the service first , service time, accurate recording system, timeliness of service, speed of service, the performance of the workers and therapists, the ability of workers and therapists, the response of workers to the consumer, confidence in the workers and therapists, the feeling of payment transactions, courtesy workers, knowledge workers, cooperation between workers and consumers while providing services, personal attention to customers, understanding the special needs of workers to the consumer,

menu Bali in the process of treatment, the use of herbs and spices - spices in the spa, Bali product usage in the spa, the use of wellknown branded products in the spa, and the use of local technology in the spa. Five aspects are used to measure performance and consumer expectations spa services in Bali in this study, was adopted from the Thermes Marins Bali Indonesia is officially used to measure the performance of the spa destinations. The fifth aspect consists of (1) the atmosphere (ambience), (2) equipment and design, (3) the qualifications and skills of the therapist, (4) treatment menu, and (5) the quality of services (service).

\section{Atmosphere of spa services}

Atmosphere of spa services in this study is atmospheric ambience that indirectly influence the perception of tourists in assessing the performance of spa services. The ambiance / atmosphere can be an attraction for consumers, for example their resting place, space maintenance, cleanliness, and appearance of the officer at the spa.

\section{Equipment and spa services design}

Equipment and design of spa services in this study is the equipment and spa design that indirectly influence the perception of tourists in assessing the aesthetic and quality spa. Hardware support is an important matter that can affect the perception of tourists to health care. Designs can be the selection of spa services spa location, traffic conditions, environmental conditions and layout of the spa.

\section{Qualifications and skills of spa therapist}

Spa therapist qualifications and skills in this research is a skill that should be owned by the workers of the spa formal or informal education to meet competency as a spa therapist. Skills can be the timeliness of service, speed of service, the performance of the workers and therapists, the response of workers to the consumer, confidence in the workers and therapists, courtesy of the workers, knowledge workers, cooperation between workers and consumers while providing service, attention personal to the consumer, and understanding the special needs of workers against consumers. 


\section{Menu of spa treatment services}

Menu of service spa treatment in this study are a number of methods and techniques of spa services that can be performed by spa therapists, which consists of a menu indicator Bali in the process of treatment. Menu treatment spa services can be of service with the use of herbs and spices - spices, use of local products Bali, and the use of well-known branded products in the spa.

\section{Quality of spa services}

Quality of spa services in this study is the performance of a number of indicators of spa services that can be the use of local technology, the latest technology, the use of materials - materials that have been known in the spa whose quality has been recognized, including all aspects of the stage before treatment services, processes, and end services in the form of correspondence between the expectations of consumers with a performance that has been provided by the spa services for all product attributes.

\section{Hypothesis}

Based on the above literature review, then the research hypothesis formulated is "no difference between the performance and consumer expectations towards spa services in Bali in terms of utilization of natural resources, human resources, and local knowledge of Bali", and "there is no influence of the use of resources natural resources, human resources and local knowledge of the existence and the essence of spa in Bali ".

\section{Methodology}

\section{Research design}

This research is a quantitative research conducted by survey method. This research design applying methods - methods to examine the relationship between variables. In the survey study, researchers identify the characteristics of the respondents in the form of traveler demographic data such as age, nationality, education, and how they recognized spa in Bali, industry characteristics or spa businesses in obtaining data on the payload environment spa and local resources in running the spa business practices; and rating of data about the performance of services in terms of various indicators spa spa services.

\section{Location and time of the research}

This research was conducted during the period of six months, which have been carried out from April to October 2014, located in two districts, namely Badung regency especially the area of Nusa Dua, Jimbaran, Kuta. While in Gianyar take place in Ubud area. The reason only been two districts because only in two districts there are many businesses tersebutlah spa services. The next reason is Badung has an atmosphere livelier, warmer and more location near the beach because it is part of the hotel service facilities. As well as Ubud in Gianyar in particular that has a cooler atmosphere, and the location is not just rely on the beauty of the beach, but also rice fields, rivers, and cliffs.

\section{Variables of the research}

The research variables consisted of independent variables and the dependent variable. As independent variables are: the performance of the utilization of local natural resources, human resources, local, local techniques in spa services and local processing technology in making products supporting the spa. While the dependent variable is: the relationship between service indicators in utilizing local natural resources, human resources, local, local techniques in spa services and local processing technology in making products supporting the spa.

\section{Results and Discussion}

This research is located in two districts, namely Badung especially Nusa Dua, Jimbaran, Kuta and Gianyar regency especially in the area of Ubud. This refers to the number of spas are scattered in the area and to determine whether the study was able to contribute to the improvement of natural resources and local human resources, per capita income, in an effort to improve the existence and essence of Bali in the spa, and is not Direct preserving, conserving local wisdom and culture. Spa types to conduct a survey dominated by business type and partly Day Spa Resort Spa, totaling $237 \mathrm{Spa}$ is 
located in Jimbaran, Nusa Dua, Jimbaran Down, Up Jimbaran, Kuta, Kuta, Legian, Seminyak and Ubud. Questionnaires were distributed to foreign tourists on each spa is not the same because it is adjusted to the spa that made the object of research and depending percentage of the number of consumers who were treated at the spa.

Analysis of the results in shows that the assessment of perceptions and expectations of the travelers in Bali spa service performance by using analysis of 16 indicators including servqual that ideal categories, and 12 including still less than ideal. Average - The average value of the perception of spa services in Badung and Gianyar was 3.98, while the average - average value of expected tourists is 3.96, which means that the perception is still higher than the expected value that is equal to 0.02 so that the overall Bali spa service performance in accordance with customer expectations. According to the analysis servqual, satisfaction is compatibility between the expectations of the performance of the service. Based on the analysis that has been done, it is evident that the average - average value for the perception / performance is higher than the expectation / expectations so that customer satisfaction can be said to have been achieved.

From 28 indicators that were analyzed, there are 12 indicators that otherwise less than ideal or performance needs to be improved. The indicator is the realization of a promise, sympathy and atitude, the accuracy of the first service, timeliness of service, the performance of the workers and therapists, the ability of workers and therapists, the response of workers to the consumer, confidence in the workers and therapists, personal attention to consumers, workers understanding of the special needs of consumers, and the use of well-known branded products in the spa, and the use of local technology in the spa.

\section{Conclusion and Recommendation}

\section{Conclusion}

The survey has involved 400 consumers spa services in Bali has managed to conclude that the overall performance of services spa in Bali has been performed in accordance with customer expectations. Performance has been in line with expectations of consumers have been able to realize customer satisfaction because there is no real difference between performance and perception of the consumer. Conclusion the results of the analysis can be broken down as follows:

1. Performance spa services in terms of utilization of natural resources, human resources, and local wisdom of Bali, particularly in terms of (1) the atmosphere (ambience), (2) equipment and design, (3) the qualifications and skills of the therapist, (4) treatment menu, and (5) the quality of services (service) as a whole has shown good performance. However, consumer expectations of the spa service indicators in terms of utilization of natural resources, human resources, and local wisdom of Bali, particularly in terms of (1) the atmosphere (ambience), (2) equipment and design, (3) the qualifications and skills of the therapist, (4) The treatment menu, and (5) the quality of services as a whole have demonstrated the value of important categories.

2. The effect of the utilization of natural resources, human resources and local knowledge of the existence and the essence of spa in Bali, found there was no real difference between expectations and performance in Bali spa services, especially in terms of (1) the atmosphere (ambience), (2) equipment and design, (3) the qualifications and skills of the therapist, (4) treatment menu, and (5) the quality of services.

Indicators - performance that are categorized as less than ideal with consumer expectations, are: the realization of the promise, sympathy and attitude, the accuracy of the first service, timeliness of service, the performance of the workers and therapists, the ability of workers and therapists, the response of workers to the consumer, confidence in the workers and therapists, personal attention to customers, understanding the special needs of workers to the consumer, the use of wellknown branded products in the spa, and the use of local technology in the spa. Meanwhile, indicators - performance indicators that are 
categorized as ideal and in accordance with customer expectations are: a method bali in spa massage techniques, the latest methods in the technique of massage spa, Balinese, physical care, time of operation, characteristics of the Balinese therapists, service time, recording system accurate, speed of service, the feeling of payment transactions, courtesy of the workers, knowledge workers, cooperation between workers and consumers while providing service, menu Bali in the process of treatment, the use of herbs and spices - spices in the spa, and use of the products in the spa Bali.

\section{Recommendation}

The results provide important suggestions as follows: Increase consumer confidence in the workers and therapists by providing complete information about the skills possessed by workers or therapist of spa. This can be realized by performing the certification to the spa worker or therapist to increase the confidence of consumers to services. Maintain the performance of some of the indicators that have been in accordance with the expectations of consumers. Indicators - indicators can be maintained by means of adopting it into material training program or training workers or therapists' spa. Indicators that should be maintained is as follows: (1) the realization of the promise, the realization of the promise, (2) the accuracy of the first services, (3) time of service, (4) the timeliness of services, (5) the speed of service, (6) show employment of workers and therapists, (7) the ability of workers and therapists, (8) the response of workers to the consumer, (9) the feeling of payment transactions, (10) courtesy of the workers, (11) the knowledge workers, and (12) the use of well-known branded products in the spa.

\section{References}

Barnes, J., Goc Karp, G. G. and Stoll, S. K. (2008) 'Ethical aggression in sport', Journal of Youth Sports.

Cronin Jr, J. J. and Taylor, S. A. (1992) 'Measuring service quality: a reexamination and extension', The journal of marketing. JSTOR, pp. 5568.

http://ojs.unud.ac.id/index.php/eot
Grönroos, C. (1984) 'A service quality model and its marketing implications', European Journal of marketing. MCB UP Ltd, 18(4), pp. 36-44.

Kim, K. (2002) 'The effects of tourism impacts upon quality of life of residents in the community'. Virginia Polytechnic Institute and State University.

Lewis, R. C. and Booms, H. (1983) 'The Marketing of Service Quality: In emerging Perspectives on Service Marketing, eds', Berry, L., Shostack, G., and Upah, G., AMA, Chicago.

MacKay, K. J. and Fesenmaier, D. R. (2000) 'An exploration of cross-cultural destination image assessment', Journal of travel research. Sage Publications Sage CA: Thousand Oaks, CA, 38(4), pp. 417-423.

Oliver, R. L. (1981) 'Measurement and evaluation of satisfaction processes in retail settings.', Journal of retailing. Elsevier Science.

Parasuraman, A., Zeithaml, V. A. and Berry, L. L. (1985) 'A conceptual model of service quality and its implications for future research', the Journal of Marketing. JSTOR, pp. 41-50.

Quintela, J. A., Correia, A. G. and Antunes, J. G. (2011) 'Service quality in health and wellness tourism-trends in Portugal', International Journal of Business, Management and Social Sciences, 2(3), pp. 1-8.

Schüler, J., Sheldon, K. M. and Fröhlich, S. M. (2010) 'Implicit need for achievement moderates the relationship between competence need satisfaction and subsequent motivation', Journal of Research in Personality. Elsevier, 44(1), pp. 1-12.

Smith, M. and Puczkó, L. (2010) 'Taking your life into your own hands? New trends in European health tourism', Tourism Recreation Research. Taylor \& Francis, 35(2), pp. 161-172.

e-ISSN: 2407-392X. p-ISSN: 2541-0857 
Supapol, A. B., Barrows, D. and Barrows, A. (2007) 'Canadian health and wellness tourism: Obstacles impeding international competitiveness', The Innovation Journal: The Public Sector Innovation Journal, 12(3), pp. 1-18.

Widjaya, L. (2011) 'Spa Industry in Bali', Guest Lecturer in Tourism Doctoral Program at Udayana University.

Zeithaml, V., Bitner, M. J. and Gremler, D. D. (1996) 'Services Marketing. Series in Marketing'. McGraw-Hill. 